\title{
Promising neuroprotective effects of oligostilbenes
}

\author{
Hamza Temsamani, Stéphanie Krisa, Jean-Michel Mérillon and Tristan Richard* \\ Université de Bordeaux, ISVV, EA 3675 GESVAB, 33140 Villenave d'Ornon, France
}

\begin{abstract}
Stilbenes (resveratrol derivatives) are a polyphenol class encountered in a large number of specimens in the vegetal realm. They adopt a variety of structures based on their building block: resveratrol. As the most widely studied stilbene to date, resveratrol has shown multiple beneficial effects on multiple diseases and on neurodegenerative diseases. Except for resveratrol, however, the biological activities of stilbenes have received far less attention, even though some of them have shown promising effects on neurodegenerative disease. This review covers the chemistry of stilbenes and offers a wide insight into their neuroprotective effects.
\end{abstract}

Keywords: Resveratrol, stilbene, oligostilbene, neuroprotection

\section{Introduction}

Even if "French paradox" [1] is not universally accepted [2], evidences of beneficial effects of wine consumption on health were validated [3-5] and since then has led to a growing interest in polyphenols. Many of these natural secondary metabolites have been investigated owing to their beneficial effects on human health. Indeed, studies have demonstrated a correlation between moderate wine consumption and a decrease in the risk of cancer, cardiovascular diseases and neurodegenerative diseases [6]. Polyphenols are thought to be responsible for this correlation [7].

Resveratrol is considered to be one of the wine polyphenols underpinning the "French Paradox" [8]. It is a powerful antioxidant with several beneficial impacts on health [9], especially its ability to prevent neurodegenerative diseases $[10,11]$. It is the main building block of wine stilbenes [12]. Studies have demonstrated that stilbenes share the ability of resveratrol in having potentially positive effects on health [13-15]. This manuscript summarizes the main results

\footnotetext{
*Corresponding author: T. Richard, Université de Bordeaux, ISVV, EA 3675 GESVAB, 33140 Villenave d'Ornon, France. Tel: +33 557 122 710; Fax: +33 557122 717; E-mail: tristan.richard@ u-bordeaux.fr.
}

concerning the derivatives of resveratrol and their protective effects on neurodegenerative diseases.

\section{Polyphenols and stilbenes}

Stilbenes constitute a class of phenolic compounds $[16,17]$. Polyphenols are mainly synthesized trough the shikimate pathway and are characterized by at least one hydroxyl group linked to an aromatic cycle. They can be divided into two groups: flavonoid and nonflavonoid compounds. Flavonoids are characterized by a typical structure on C6-C2-C6 and are synthesized through the malonate pathway. They are mainly available in their glycosylated forms in plants and are often colored. Many compound families are included within the flavonoids: flavonols, flavonols, flavones, isoflavones, flavanones and anthocyanins.

The basic skeleton of stilbenes comprises two aromatic rings joined by an ethylene bridge (Fig. 1). This basic structure gives rise to a wide range of different compounds: monomers differing in the number and position of their hydroxyl groups, substitution with sugars and other residues and the steric configuration of the molecules; condensation of the monomers leading to the formation of complex oligomers [18]. 
<smiles>Oc1ccc(/C=C/c2cc(O)cc(O)c2)cc1</smiles><smiles>Oc1cc(O)cc(/C=C/c2ccc(O)c(O)c2)c1</smiles><smiles>COc1ccc(/C=C/c2cc(O)cc(O)c2)cc1O</smiles><smiles>COc1cc(/C=C/c2ccc(O)cc2)cc(OC)c1</smiles><smiles>Oc1ccc(C=Cc2cc(O)cc(OC3CCCCC3)c2)cc1</smiles><smiles>Oc1cc(/C=C/c2ccc(O)c(O)c2)cc(OC2CCCCC2)c1</smiles><smiles>COc1cc(/C=C/c2cc(O)cc(O)c2)ccc1O</smiles><smiles>Oc1cc(O)cc(C=Cc2ccccc2)c1</smiles>

Fig. 1. Main monomeric stilbenes.

Vine derivatives such as table grapes, grape juice and wine are the main dietary source of stilbenes in the Western diet. Their concentration in wine is about 10 milligrams per liter [19]. They are also found in the range of a few milligrams to a few hundred milligrams per kilogram of dry matter in various dietary sources such as raisins, red fruits, peanuts and rhubarb [19]. Resveratrol is the most well-known stilbene. It was first described as a vine phytoalexin [20] but further studies showed it to be a beneficial compound for health [21]. Resveratrol is nowadays renowned as a powerful anti-oxidant and anti-inflammatory, and is thus associated with the beneficial impact of moderate wine consumption on health, especially with regard to the cardiovascular diseases, cancer, aging and even the neurodegenerative diseases.

Compared to resveratrol, the other stilbenes have received less attention. The presence of stilbene oligomers was recently reported in wine [22, 23]. Nevertheless, the stilbene content in wine remains unrecognized [24]. Recent results indicate that the biological activities of other stilbenes are at least equal to those of resveratrol. Hopeaphenol and vitisin A, two oligomers, inhibit propagation of the canine tumor cellline more efficiently than resveratrol [25]. $\varepsilon$-viniferin glucoside and scirupsin A are two dimers with a better inhibition than resveratrol on the aggregation of $\beta$-amyloid peptide, a peptide involved in Alzheimer's disease [13]. Thus, some stilbenes could prove to be more promising beneficial compounds than resveratrol against specific diseases.

\section{Resveratrol bioavailability}

Studies on the bioavailability of stilbenes have focused mainly on resveratrol at the expense of the other stilbenes. Resveratrol bioavailability has been studied in animal models and human [26-29]. Its intestinal absorption in rat is as high as $70 \%$ [27]. 
Table 1

Maximum content of piceid (resveratrol glucoside) in organs of mice after oral administration of piceid $50 \mathrm{mg} / \mathrm{kg}$ body weight [30]

\begin{tabular}{lc}
\hline Tissues & Concentration $(\mu \mathrm{g} / \mathrm{g})$ \\
\hline Heart & 5.0 \\
Liver & 4.5 \\
Spleen & 28.0 \\
Lung & 10.4 \\
Kidney & 2.6 \\
Stomach & 168.8 \\
Small intestine & 108.7 \\
Brain & 6.1 \\
Testis & 29.1 \\
\hline
\end{tabular}

Once absorbed, it is metabolized into its glucoronides and sulfoconjugates [27, 28]. In our laboratory, we monitored the distribution of ${ }^{14} \mathrm{C}$-resveratrol in mouse tissue 3 hours after oral intake [29]. Radioactivity was recorded in the brain, lungs, heart, liver, kidneys, spleen, colon, and testicles. The highest concentrations were detected in the duodenum and kidneys and the lowest in the heart, testicles and brain. Pharmacokinetics and tissue distribution of piceid (resveratrol glucoside) following a single oral dose of $50 \mathrm{mg} / \mathrm{kg}$ were studied in rat model [30]. The result shows that piceid is quickly absorbed, at $10 \mathrm{~min}$, the concentrations of piceid in most tissues reached peak level. The tissue distribution of piceid was presented in Table 1. Piceid was absorbed throughout the gastrointestinal tract with considerable absorption taking place in the stomach and small intestine. There was no longterm accumulation of piceid in rat tissues. Resveratrol and its derivatives are thus able to penetrate tissues. Nevertheless the bioavailability of stilbene oligomers remains unknown. No supposition about bioavailability can be made only regarding a stilbene structure. About the Brain Blood Barrier (BBB), only resveratrol has been studied far enough to show an ability to cross the BBB. One can suppose that complex stilbenes will not be able to cross the BBB. But the dimers could cross it. The commercialization of stilbene dimers such as $\varepsilon$-viniferin will allow addressing this problem.

\section{Stilbenes and neurodegenerative diseases}

Neurodegenerative diseases like Alzheimer disease still cannot be treated efficiently yet populations are globally growing older, especially in the industrialized countries. Medical research is currently seeking ways to overcome this public health issue and the discovery of compounds with the ability to treat and prevent brain injuries is one of the most promising avenues of investigation. Stilbenes, and particularly resveratrol, have displayed interesting neuroprotective activities.

As for bioavailability, most of the studies on the neuroprotective effects of stilbenes have focused on resveratrol. Resveratrol is known to act through various mechanisms to prevent the two most widespread neurodegenerative diseases, Alzheimer's and Parkinson's diseases [10, 31].

Alzheimer's disease is the most widespread neurodegenerative disease. Two proteins are involved in this disease: $\tau$-protein and amyloid $\beta$-peptide $(A \beta)$. Their excessive accumulation triggers a cellular dysfunction [32]. Neuron cytoskeletons are stabilized by $\tau$-protein but abnormal clusters of this phosphorylated protein can form into cells and are an initial hallmark of Alzheimer's disease. Extracellular aggregation of $A \beta$ is the second hallmark. $A \beta$ is the product of the sequential proteolytic cleavage of the transmembrane protein APP (Amyloid Protein Precursor) by two enzymes: a $\beta$-secretase and a $\gamma$-secretase. Aggregation of this toxic and insoluble peptide leads to the onset of amyloid plaques, also known as senile plaques. Those plaques induce oxidative stress and an inflammatory process, in addition to the neuronal malfunction. This amyloid cascade triggers several phenomena leading to neuronal death (Fig. 2).

Resveratrol has shown its ability to interfere with this amyloid cascade (Fig. 2). It decreases the accumulation of reactive oxygen species (ROS) and protects the PC12 cell-line against A $\beta$-induced damage [33]. It inhibits the chemical mediators of inflammation on microglial cells, modulates the lipoxygenase and cyclo-oxygenase enzymes and inhibits inductive nitric oxide synthase (iNOS) and the production of cytokines and transcription factors [34]. It is thought to act on proteasome activation by reducing the $A \beta$ secretion on cell lines transfected with the APP 695 gene, without any direct impact on the secretases activated during $A \beta$ synthesis [35]. Moreover, resveratrol can inhibit $A \beta$ aggregation in a specific manner [36]. Altogether these data underline the ability of resveratrol to be a neuroprotective agent against Alzheimer's disease. Indeed, the neuroprotective effects of resveratrol are currently under clinical evaluation. In the United States, a phase 2 clinical study funded by the National Institute of Aging (NIA) and named "Resveratrol for Alzheimer's disease" is underway and the results should be published by 2015 . 


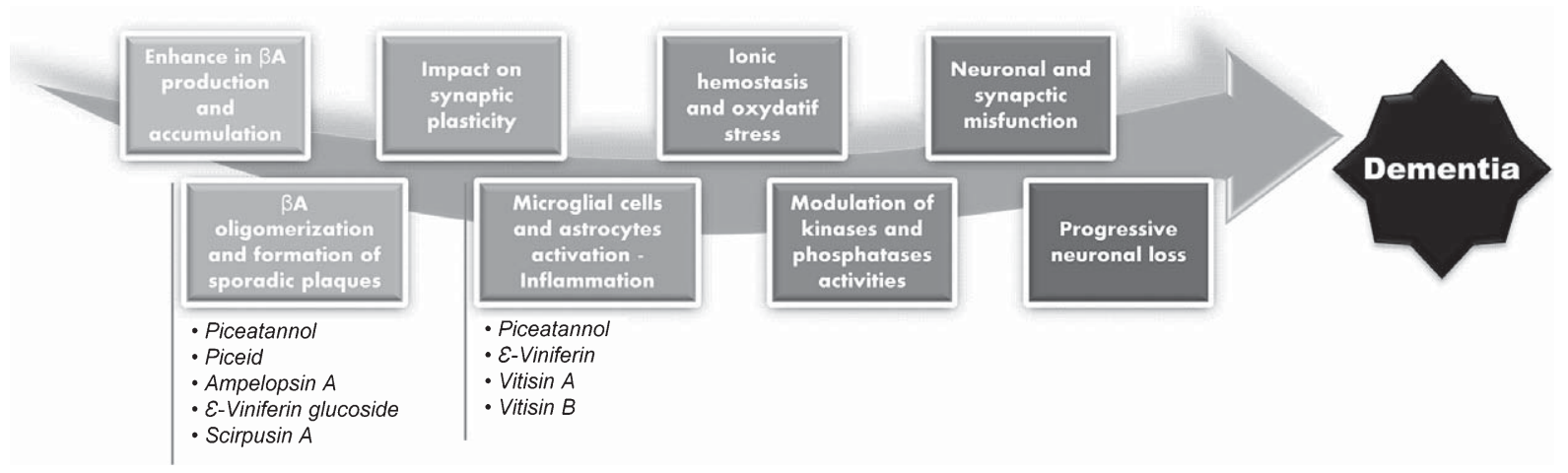

Fig. 2. Stilbenes and steps in amyloidic cascade leading to dementia.

Table 2

Inhibition of $\mathrm{A} \beta$ fibril formation [13]

\begin{tabular}{lcc}
\hline Compounds & Inhibition $\%$ & $\mathrm{EC}_{50}(\mu \mathrm{M})$ \\
\hline monomers & & \\
resveratrol & $63 \pm 6$ & $6 \pm 2$ \\
piceid & $62 \pm 6$ & $6 \pm 2$ \\
piceatannol & $25 \pm 9$ & - \\
dimers & & \\
ampelopsin A & $46 \pm 6$ & $10 \pm 2$ \\
scirpusine A & $80 \pm 9$ & $0.7 \pm 0.3$ \\
$\varepsilon$-viniférine glucoside & $93 \pm 3$ & $0.2 \pm 0.3$ \\
\hline
\end{tabular}

Others stilbenes could also be promising neuroprotective agents. Various stilbenes have been tested in our laboratory, including five compounds that displayed a higher activity than curcumin, a powerful inhibitor of $\mathrm{A} \beta$ aggregation $[13,36]$ : resveratrol, piceid, its glucoside, ampelopsin A, $\varepsilon$-viniferin glucoside and scirpusin A (Table 2). Dimers like $\varepsilon$-viniferin glucoside and scirpusin A appear to be the most active whereas the oligomers $(n>2)$ tend to be less active, implying a specific structure-activity relationship. The decrease in the interaction with the peptide could be due to the steric hindrance of the compounds. $\varepsilon$-viniferin glucoside showed its ability to inhibit $A \beta$-induced toxicity on PC12 cell lines in a complementary study [37]. Another study with mass spectrometry and NMR demonstrated that $A \beta$ aggregation into fibrils is inhibited at an early step [38]. These results point to the formation of a complex between two polyphenol molecules and one $A \beta$ molecule. Once included in this complex, the peptide could not change its conformation nor aggregate into fibrils. In addition, we have also shown that resveratrol, piceatannol, $\varepsilon$-viniferin and vitisin $\mathrm{A}$ and $\mathrm{B}$ are able to inhibit the production of nitrogen monoxide, a hallmark of inflammation, by decreasing the expression of the corresponding genes and proteins [14]. These findings demonstrate the protective effect of stilbenes against lipopolysacharide-induced inflammation on microglial cells (BV2 cell lines).

\section{Conclusion}

Altogether, the data presented herein show that stilbenes could be among the most promising polyphenols for preventing neurodegenerative diseases. Studies on resveratrol have demonstrated that it can potentially act on various targets linked to the neurodegenerative process. Although the effects of resveratrol on Alzheimer's disease are currently being assessed in a clinical study in the United States, stilbenes other than resveratrol are potentially interesting compounds according to an increasing line of evidence. Nevertheless, the properties of stilbene oligomers remain unknown. Characterizing their mechanisms of action and bioavailability could lead to the development of some of the most potent compounds yet discovered for the prevention and treatment of neurodegenerative diseases.

\section{References}

[1] Renaud S, Lorgeril M. Wine, alcohol, platelets, and the French paradox for coronary heart disease. The Lancet. 1992;339:1523-6.

[2] Fillmore KM, Stockwell T, Chikritzhs T, Bostrom A, Kerr W. Moderate Alcohol Use and Reduced Mortality Risk: Systematic Error in Prospective Studies and New Hypotheses. Ann Epidemiol. 2007; 17:S16-S23. 
[3] Caderni G, De Filippo C, Luceri C, Salvadori M, Giannini A, Biggeri A, Remy S, Cheynier V, Dolara P. Effects of black tea, green tea and wine extracts on intestinal carcinogenesis induced by azoxymethane in F344 rats. Carcinogenesis. 2000;21:1965-9.

[4] Arntzen KA, Schirmer H, Wilsgaard T, Mathiesen EB. Moderate wine consumption is associated with better cognitive test results: A 7 year follow up of 5033 subjects in the Troms $\varnothing$ Study. Acta Neurol Scand. 2010;122:23-9.

[5] Kondrashov A, Vranková S, Dovinová I, Ševčík R, Parohová J, Barta A, Pecháňová O, Kovacsová M. The effects of new alibernet red wine extract on nitric oxide and reactive oxygen species production in spontaneously hypertensive rats. Oxid Med Cell Longev. 2012;ID 806285.

[6] Gronbaek M, Deis A, Sorensen T, Becker U, Schnohr P, Jensen G. Mortality associated with moderate intakes of wine, beer, or spirits. BMJ. 1995;310:1165.

[7] Sun AY, Simonyi A, Sun GY. The "French Paradox" and beyond: Neuroprotective effects of polyphenols. Free Radic Biol Med. 2002;32:314-8.

[8] Liu B, Zhang X, Zhang W, Zhen H. New enlightenment of French paradox: Resveratrol's potential for cancer chemoprevention and anti-cancer therapy. Cancer Biol Ther. 2007;6:1833-36.

[9] Fernández-Mar MI, Mateos R, García-Parrilla MC, Puertas B, Cantos-Villar E. Bioactive compounds in wine: Resveratrol, hydroxytyrosol and melatonin: A review. Food Chem. 2012;130:797-813.

[10] Anekonda TS. Resveratrol - a boon for treating Alzheimer's disease? Brain Res Rev. 2006;52:316-26.

[11] Rege SD, Kumar S, Wilson DN, Tamura L, Geetha T, Mathews ST, Huggins KW, Broderick TL, Babu JR. Resveratrol protects the brain of obese mice from oxidative damage. Oxid Med Cell Longev. 2013;419092.

[12] Pawlus AD, Waffo-Teguo P, Shaver J, Merillon JM. Stilbenoid Chemistry from Wine and the Genus Vitis. J Int Sci Vigne Vin. 2012;46:57-111.

[13] Rivière C, Papastamoulis Y, Fortin PY, Delchier N, Andriamanarivo S, Waffo-Téguo $\mathrm{P}$, Kapche GD, AmiraGuebalia H, Delaunay JC, Mérillon JM, Richard T, Monti JP. New stilbene dimers against amyloid fibril formation. Bioorg Med Chem Lett. 2010;20:3441-3.

[14] Nassra M, Krisa S, Papastamoulis Y, Kapche GD, Bisson J, André C, Konsman JP, Schmitter JM, Mérillon JM, Waffo-Téguo P. Inhibitory activity of plant stilbenoids against nitric oxide production by lipopolysaccharide-activated microglia. Planta Med. 2013;79:966-70.

[15] Richard T, Temsamani H, Delaunay JC, Krisa S, Mérillon JM. Stilbènes: De la chimie à la neuroprotection. Cah Nutr Diet. 2014;49:173-80.

[16] Bruneton J. Pharmacognosie - Phytochimie, plantes médicinales, 4e éd., revue et augmentée. Paris: Tec \& Doc - Éditions médicales internationales; 2009.

[17] Rivière C, Pawlus AD, Mérillon JM. Natural Stilbenes: Distribution in the plant kingdom and chemotaxonomic interest in Vitaceae. Nat Prod Rep. 2012;29:1317-33.

[18] Papastamoulis Y, Richard T, Nassra M, Badoc A, Krisa S, Harakat D, Monti JP, Mérillon JM, Waffo-Teguo P. Viniphenol A, a Complex Resveratrol Hexamer from Vitis vinifera Stalks:
Structural Elucidation and Protective Effects against Amyloid$\beta$-Induced Toxicity in PC12 Cells. J Nat Prod. 2014;77:213-7.

[19] Pérez-Jiménez J, Neveu V, Vos F, Scalbert A. A systematic analysis of the content of 502 polyphenols in 452 foods and beverages - An application of the Phenol-Explorer database. J Agric Food Chem 2010;58:4959-69.

[20] Jeandet P, Douillet-Breuil AC, Bessis R, Debord S, Sbaghi M, Adrian M. Phytoalexins from the Vitaceae: Biosynthesis, Phytoalexin Gene Expression in Transgenic Plants, Antifungal Activity, and Metabolism. J Agric Food Chem. 2002;50: 2731-41.

[21] Vang O, Ahmad N, Baile CA, Baur JA, Brown K, Csiszar A, Das DK, Delmas D, Gottfried C, Lin HY, Ma QY, Mukhopadhyay P, Nalini N, Pezzuto JM, Richard T, Shukla Y, Surh YJ, Szekeres T, Szkudelski T, Walle T, Wu JM. What Is New for an Old Molecule? Systematic Review and Recommendations on the Use of Resveratrol. PLoS One. 2011;6:e19881.

[22] Vitrac X, Bornet A, Vanderlinde R, Valls J, Richard T, Delaunay JC, Mérillon JM, Teissédre PL. Determination of stilbenes ( $\delta$-viniferin, trans-astringin, trans-piceid, cis- and trans-resveratrol, $\varepsilon$-viniferin) in Brazilian wines. J Agric Food Chem. 2005;53:5664-9.

[23] Pawlus AD, Cantos-Villar E, Richard T, Bisson J, Poupard P, Papastamoulis Y, Monti JP, Teissedre PL, Waffo-Téguo P, Mérillon JM. Chemical dereplication of wine stilbenoids using high performance liquid chromatography-nuclear magnetic resonance spectroscopy. J Chromatogr A. 2013;1289: 19-26.

[24] Waffo-Téguo Pierre P, Krisa S, Pawlus AD, Richard T, Monti JP, Merillon JM. Grapevine stilbenoids: Bioavailability and neurprotection, in Merillon JM and Ramawat KG, editors. Handbook of Natural Products: Phytochemistry, Botany and Metabolism of Alkaloids, Phenolics and Terpenes. Berlin: Springer Berlin Heidelberg; 2013. pp. 2275-309.

[25] Empl MT, Macke S, Winterhalter P, Puff C, Lapp S, Stoica G, Baumgärtner W, Steinberg F. The growth of the canine glioblastoma cell line D-GBM and the canine histiocytic sarcoma cell line DH82 is inhibited by the resveratrol oligomers hopeaphenol and r2-viniferin. Vet Comp Oncol. 2014;12:149-59.

[26] Soleas GJ, Yan J, Goldberg DM. Measurement of transresveratrol, (+)-catechin, and quercetin in rat and human blood and urine by gas chromatography with mass selective detection. Methods Enzymol. 2001;335:130-45.

[27] Soleas GJ, Angelini M, Grass L, Diamandis EP, Goldberg DM. Absorption of trans-resveratrol in rats. Methods Enzymol. 2001; 335:145-54.

[28] Aumont V, Krisa S, Battaglia E, Netter P, Richard T, Mérillon JM, Magdalou J, Sabolovic N. Regioselective and stereospecific glucuronidation of trans- and cis-resveratrol in human. Arch Biochem Biophys. 2001;393:281-9.

[29] Vitrac X, Desmoulière A, Brouillaud B, Krisa S, Deffieux G, Barthe N, Rosenbaum J, Mérillon JM. Distribution of [14C]-trans-resveratrol, a cancer chemopreventive polyphenol, in mouse tissues after oral administration. Life Sci. 2003;72: 2219-33.

[30] Lv C, Zhang L, Wang Q, Liu W, Wang C, Jing X, Liu Y. Determination of piceid in rat plasma and tissues by high-performance liquid chromatographic method with UV detection. Biomed Chromatogr. 2006;20:1260-6. 
[31] Jin F, Wu Q, Lu YF, Gong QH, Shi JS. Neuroprotective effect of resveratrol on 6-OHDA-induced Parkinson's disease in rats. Eur J Pharmacol. 2008;600:78-82.

[32] Hardy JA, Selkoe DJ. The amyloid hypothesis of Alzheimer's disease: Progress and problems on the road to therapeutics. Science. 2002;297:353-6.

[33] Jang JH, Surh YJ. Protective effect of resveratrol on $\beta$-amyloidinduced oxidative PC12 cell death. Free Radic Biol Med. 2003;34:1100-10.

[34] Zhang F, Liu J, Shi JS. Anti-inflammatory activities of resveratrol in the brain: Role of resveratrol in microglial activation. Eur J Pharmacol. 2010;636:1.

[35] Marambaud P, Zhao H, Davies P. Resveratrol promotes clearance of Alzheimer's disease amyloid- $\beta$ peptides. J Biol Chem. 2005;280:37377-82.
[36] Rivière C, Richard T, Vitrac X, Mérillon JM, Valls J, Monti JP. New polyphenols active on $\beta$-amyloid aggregation. Bioorg Med Chem Lett. 2008;18:828-31.

[37] Richard T, Poupard P, Nassra M, Papastamoulis Y, Iglésias ML, Krisa S, Waffo-Teguo P, Mérillon JM, Monti JP. Protective effect of $\varepsilon$-viniferin on $\beta$-amyloid peptide aggregation investigated by electrospray ionization mass spectrometry. Bioorg Med Chem. 2011;19:3152-5.

[38] Richard T, Papastamoulis Y, Waffo-Teguo, Monti JP. 3D NMR structure of a complex between the amyloid $\beta$ peptide (1-40) and the polyphenol $\varepsilon$-viniferin glucoside: Implications in Alzheimer's disease. Biochim Biophys Acta. 2013; 1830: 5068-74. 